\title{
REFRESENTASI MASYARAKAT TURATEA DALAM SISTEM PENAMAAN (Representation of the Turatea Society in Their Naming System)
}

\author{
Ramlah Mappau \\ Balai Bahasa Sulawesi Selatan \\ Jalan Sultan Alauddin km 7 Tala Salapang, Makassar \\ Telepon (0411) 882401, Faksimile (0411) 882403 \\ Pos-el: rmappau@yahoo.com
}

\begin{abstract}
Every people group has its own naming system, a practice with unique ways and characteristics that reflect the thoughts, value, and social status of individuals and of the community, as is the case among the Turatea people, who practice "self naming" (areng karrasa) and "daeng naming" (areng pakdaengang). The community supporting the culture is undergoing change in their view toward self-naming (proper name). Cultural assimilation is also taking place, leading to the erosion of ancestral cultural values and the gradual fading of the traditionalism of the society. The paradigm used to analyze the naming system was anthropological linguistics, while applying the field survey techniques of participation, self immersion in the community, and consulting library data, especially history books. The data collected consisted of the names of those born or living in the 1900s up until the present. Next, the data was recorded, classified and analysed, using the qualitative descriptive method, with the aim of describing and expressing the meaning behind the naming of Turatea people as a naming system and linking it with the existing cultural values in the community based on the resultant meaning. The results of the study indicate that the two names assigned to a given individual using the two naming methods are connected through both phonological plays on the first name and an application of semantic logic and carry both meaning and cultural values. There is also an implied meaning behind the names given, whether the name is in the form of a noun, adjective, verb, or adverb, namely the embodiment of a command or obligation to good behavior, or a sort of benediction. Environmental states of the natural world, various circumstances, and religious knowledge are taken as the basis for naming. The two names owned by individuals in the community, areng karrasa and areng pakdaengang, each have their own application and function. The existence of the second name (areng pakdaengang/kakaraengan) is specifically associated with the middle class of society.
\end{abstract}

Keyword: naming; system; Turatea

\begin{abstract}
Abstrak
Sistem pemberian nama setiap daerah memiliki cara dan ciri tersendiri yang merefleksikan pikiran, nilai, dan status masyarakatnya, seperti halnya pemberian nama diri (areng karrasa) dan nama daeng (areng pakdaengan) pada masyarakat Turatea. Masyarakat pendukung kebudayaan tersebut mengalami perubahan pandangan terhadap pemberian nama diri (proper name). Terjadinya pembauran budaya menjadikan keluhuran nilai-nilai budaya mulai tergerus dan lambat laun
\end{abstract}


ketradisionalan masyarakatnya menjadi memudar. Paradigma yang digunakan untuk membedah sistem penamaan adalah antropolinguistik dengan teknik survei lapangan, partisipasi (participant observation) pelibatan diri dalam masyarakatnya, dan pengumpulan data pustaka: buku-buku sejarah. Data yang dikumpulkan berasal dari nama-nama yang lahir/masih hidup pada 1900an-sampai sekarang. Selanjutnya, data dicatat, diklasifikasikan, kemudian dianalisis. Metode deskriptif kualitatif dengan tujuan mendeskripsikan dan mengungkapkan makna di balik penamaan masyarakat Turatea dalam sistem penamaan dan mengaitkannya dengan nilai budaya yang ada pada masyarakatnya berdasarkan makna yang dimunculkan. Berdasarkan hasil telaah, nama pertama dengan nama kedua memiliki keterkaitan melalui permainan logika semantik yang sarat makna dan nilai budaya dan perubahan nama secara fonologis. Adapun makna di balik pemberian nama tersebut dari jenis kata benda, sifat, kerja, dan keterangan, berbentuk perintah atau keharusan untuk berbuat kebaikan dan harapan yang baik. Gejala (latar) alam semesta, keadaan, dan pengetahuan agama menjadi dasar dalam pemberian nama. Dua nama yang dimiliki oleh masyarakat, yaitu areng karrasa dan areng padaengan merupakan nama yang berbeda pemakaian dan peruntukkannya. Adanya nama kedua (areng pakdaengan/kakaraengan) hanya melekat pada kelas sosial menengah.

Kata kunci: nama; sistem; Turatea

\section{PENDAHULUAN}

Komunitas etnis atau masyarakat tradisional perlahan memudar, munculnya upaya mempertahankan ciri khas "budaya" lokal sebagai unggulan warisan leluhur patut diapresiasi. Kini kebudayaan tidaklah bersifat statis. Hal ini disebabkan oleh adanya upaya pemerintah menerapkan pasar global di Indonesia sehingga interaksi sosial budaya masyarakat semakin luas dan terbuka, mengarahkan masyarakat pada suatu keadaan imajiner, yang mulai mengabaikan batas geografis, etnografis, negara bahkan bangsa. Perubahan nilai dan perilaku masyarakat, yang tentunya dapat mengancam budaya yang dimasukinya. Adanya stigma yang menyatakan bahwa unsur-unsur kebudayaan lain tidak dapat dimasukkan ke dalam kebudayaan tanpa melakukan perubahan. Stigma tersebut tidak dapat dimungkiri karena pada dasarnya manusia cepat mengadopsi informasi yang masuk. Padahal, keluhuran budaya lokal yang adiluhung dan bersahaja itu adalah identitas budaya masyarakatnya.

Salah satu aspek perubahan budaya dapat diketahui publik melalui bahasa. Hasyim (2016) masyarakat dalam kehidupan sosial yang penuh dinamika senantiasa mengalami perkembangan dan perubahan dalam berbagai sistem kehidupannya. Perubahan itu terlihat dan terwadahi dalam rekaman bahasa. Bahasa dalam kehidupan sehari-hari dapat merefleksikan pikiran, identitas, jati diri masyarakat, atau dengan kata lain cerminan budaya masyarakatnya. Pemberian nama merupakan salah satu upaya mengetahui nilai budaya masyarakat pemiliknya. Hal terkait dengan pendapat Iswary (2010: 52) bahwa setiap bahasa yang diekspresikan dalam bentuk leksikal merupakan representasi atau realitas dari budaya terkait. Sufika (2007: 68) berpendapat bahwa bahasa merupakan bagian dari budaya yang erat kaitannya dengan cara berpikir penuturnya. Dengan demikian, bahasa dapat merepresentasikan cara berpikir dan budaya masyarakat penuturnya. Selain nama sebagai representasi pikiran, nama juga digunakan sebagai penanda identitas seseorang. Sebagaimana pernyataan Kridalaksana (1993: 144) bahwa kata yang dipakai untuk menyebut diri seseorang. Dengan kata lain, nama diri merupakan kata yang berfungsi sebagai sebutan untuk menunjuk orang atau sebagai penanda identitas. Sibarani (1993: 8) nama adalah suatu kata atau kelompok kata yang digunakan untuk mengidentifikasi dan menyebut orang, hewan, 
benda, dan tempat. Selanjutnya, nama diri adalah kata yang digunakan untuk menyebut diri seseorang. Nama diri itu berfungsi sebagai penanda identitas seseorang. Jika dilihat dari ilmu bahasa, nama diri merupakan sebutan lingual yang dapat disebut sebagai tanda. Bromberger (dalam Sariah, 2012: 187) menyatakan bahwa antroponimi (nama diri) merupakan tanda konvensional dalam hal pengidentifikasian sosial yang merujuk secara tetap pada satu individu. Namun, dalam suatu masyarakat sebuah antroponimi tidak hanya merujuk pada satu orang.

Penanda identitas seseorang tentu berbeda antara satu daerah dengan daerah lainnya, seperti halnya di Jeneponto yang merupakan salah satu kabupaten yang terletak di bagian selatan Pulau Sulawesi yang menggunakan bahasa Makassar dengan dialek Turatea, memiliki cara/sistem menamai seseorang. Seorang anak di dalam keluarga padanya dilekatkan nama diri, yaitu areng cakdi 'nama kecil/balita', areng karrasa 'nama sakral', dan areng pakdaengan' nama kehormatan' atau areng pakkaraengan' nama kebangsawanan'.

Sistem pemberian nama itu dari waktu ke waktu mengalami perubahan sistem penamaan. Hal itu tampak, dari nama masyarakatnya yang sudah mengadopsi nama dari suku lain. Penggunaan erat kaitannya dengan logika internal (internal logic) masyarakatnya sehingga dapat saja terdapat perbedaan bahasa antara kelompok masyarakat yang sama. Namun, dalam kurun waktu yang berbeda, dapat disebabkan oleh adanya perbedaan logika kelompok masyarakat dan lingkungan yang berbeda. Aspek waktu (historis) juga menyebabkan terjadinya perubahan penggunaan bahasa. Karena itu, logika dan kognisi masyarakat tidak hanya berbeda, tetapi juga berubah karena adanya perbedaan lingkungan dan waktu serta tempat bahasa itu eksis.

Penelitian tentang penamaan sudah pernah dilakukan Salahuddin (1999) khususnya pada masyarakat Arab, Hasyim (2016) menulis "Perubahan Sistem Penamaan Nama Diri dalam
Budaya Masyarakat Etnis Makassar" yang menunjukkan bahwa penamaan masyarakat mengalami perubahan pada sistem ritual penamaan, perubahan dalam unsur pembentuk nama dan aspek leksikonnya, perubahan dalam aspek fonologisnya, serta perubahan orientasi dalam sistem budaya masyarakat etnik Makassar, dan Abbas (2012) dalam Kongres Internasional II Bahasa-Bahasa Daerah Sulawesi Selatan yang menulis tentang "Sistem Penamaan Orang Makassar" yang berpengaruh terhadap strata dan kedudukan seseorang. Kurniawaty, Laila (2007), Pemberian Nama dalam Masyarakat di Pulau Binongko. Sekaitan dengan penelitian yang berkaitan nama dan sistem penamaan orang Turatea pada aspek linguistik belum pernah dilakukan sepanjang penelusuran penulis. Sistem penamaan masyarakat Turatea antara nama diri dan nama daeng (pakdaengang) akan diungkap secara leksikal, semantis dan perubahan fonologisnya serta bagaimana nilai budayanya dalam sistem pemberian nama akan diungkap dalam tulisan ini.

\section{KERANGKA TEORI}

Penamaan sebagai suatu ekspresi kebahasaan tentu saja menunjuk dan mengonstruksi budaya. Maknun (2010: 675), mengemukakan bahwa nilai budaya disosialisasikan secara turun-temurun dari generasi ke generasi selanjutnya dan dijadikan sebagai pedoman manusia dalam bertingkah laku dalam sistem sosialnya. Dengan demikian, dapat dikatakan bahwa nama diberikan kepada seorang anak oleh orang tua adalah simbol atau label yang dilekatkan pada diri sang anak untuk memproyeksi nilai sosial dan harapan orang tuanya atau generasi sebelumnya.

Sistem pemberian nama pada masyarakat saat ini secara leksikal mengalami perkembangan, pada masa lalu nama seseorang hanya menggunakan satu atau dua kata, saat ini nama tidak hanya terdiri dari satu kata atau dua kata, tetapi mulai berkembang menjadi tiga bahkan empat kata. Saat ini pemberian nama ada yang sudah tidak mencerminkan asal atau 
agama pemilik nama karena nama dipilih dari bahasa Jawa, Arab, atau Sansekerta. Tatcher dkk. (dalam Sibarani, 2003) menyatakan bahwa ada tujuh hal yang diperhatikan dalam pemberian nama. Ketujuh hal tersebut, adalah; pertama, nama harus berharga, bernilai, dan berfaedah; kedua, nama hendaknya memiliki makna yang baik; ketiga, nama seharusnya orisinal atau asli; keempat, nama yang diberikan mudah diucapkan/dilafalkan dalam artian nama sebaiknya disesuaikan dengan pengucapan bahasa yang bersangkutan; kelima, nama seharusnya bersifat membedakan; keenam, nama harus cocok dengan nama keluarga. Nama keluarga terkadang memberikan kehormatan dan kamasyhuran terhadap seseorang yang kemungkinan berpengaruh dalam bertingkah laku; dan ketujuh, nama seharusnya membedakan jenis kelamin.

Djajasudarma (1993: 5 dan 1999: 11) menyatakan bahwa makna sebagai penghubung bahasa dengan dunia luar dibuat sesuai dengan kesepakatan para pemakainya sehingga mereka dapat saling memahami. Hubungan yang terjalin antara sebuah kata dengan barang, hal, kegiatan, atau peristiwa di luar bahasa tidak bersifat langsung, ada media yang terletak di antaranya. Kata merupakan lambang yang menghubungkan konsep dengan acuan. Mencermati bahasa mengungkapkan dan menyimbolkan realitas budaya, kajian dapat dilakukan dengan menggunakan perspektif antropologi linguistik atau yang dikenal juga dengan istilah antropolinguistik. Teori yang digunakan dalam tulisan ini adalah teori antropolinguistik dengan mengacu pada cara kerja Spradley (2006) dan Duranti (2000). Etnografi akarnya dari ilmu antropologi merupakan kegiatan penelitian untuk memahami cara orang-orang berinteraksi dan bekerja sama melalui fenomena yang teramati dalam kehidupan sehari-hari. Duranti (2000) mengenalkan konsep "linguistik-antropologi" yang ia gagas sebagai salah satu bentuk wilayah interdisipliner (interdisciplinary field) yang mempelajari "bahasa" sebagai sumber budaya (cultural resource) dan ujaran (speaking) sebagai bentuk kegiatan budaya (cultural practice). Senada dengan hal tersebut (Kramsch, 1998: 3) menyatakan bahwa katakata yang digunakan mencerminkan perilaku, sudut pandang, dan keyakinan yang dianut oleh penuturnya. Molinowski via Hymes (1964: 4) mengemukakan bahwa melalui etnolinguistik kita dapat menelusuri bagaimana bentukbentuk linguistik dipengaruhi oleh aspek budaya, sosial, mental, dan psikologis; apa hakikat sebenarnya dari bentuk dan makna dan bagaimana hubungan keduanya.

Kramsch (2000: 3) menegaskan hubungan antara bahasa dan budaya: Bahasa mengekspresikan realitas kultural, fakta, ide, peristiwa, yang dapat diteruskan karena berhubungan dengan pengetahuan tentang dunia dan merefleksikan sikap dan kepercayaan serta pandangan masyarakat; bahasa menambah realitas kultural, tidak hanya mengekspresikan pengalaman, tetapi juga menciptakan pengalaman lewat bahasa, menciptakan makna yang mudah dimengerti dan diterima oleh kelompok mereka sendiri; bahasa menyimbolisasikan realitas kultural.

Nama diri dapat pula dikaji dengan mengaitkannya dengan semantik. Spradley (2007: 154) menyatakan bahwa hubungan semantik memungkinkan pembicaraan dengan bahasa tertentu untuk merujuk pada semua selukbeluk makna yang berhubungan dengan istilahistilah penduduk aslinya. Tentu dalam hal ini, untuk menemukan makna di dalam kata-kata, perlu mendengarkan kata-kata yang digunakan oleh penutur dalam kehidupan sehari-harinya. Dalam kajian semantik diketahui jenis makna leksikal, gramatikal, referensial, konseptual, dan asosiatif. Pateda (2010: 35) mengemukakan bahwa makna leksikal adalah makna leksem ketika leksem tersebut berdiri sendiri baik dalam bentuk dasar maupun turunan dan maknanya tetap, seperti di dalam kamus. Makna referensial (konseptual) adalah makna yang berhubungan langsung dengan kenyataan atau referen (acuan). Makna referensial disebut juga makna kognitif 
karena memiliki acuan. Makna ini memiliki hubungan dengan konsep mengenai sesuatu yang telah disepakati bersama oleh masyarakat bahasa. Hubungan referensial adalah hubungan yang terdapat antara sebuah kata dan dunia luar yang diacu oleh pembicara, misalnya kamus mengacu pada sejenis buku tertentu. Hubungan antara kata (lambang), makna (konsep atau referen), dan hubungan sesuatu yang diacu (referent) merupakan hubungan tidak langsung. Hubungan tersebut digambarkan dengan segitiga semiotik (semiotic triangle) (Djajasudarma, 1993:23-24). Hubungan antara kata, makna kata, dan dunia nyata disebut hubungan referensial. Hubungan yang terdapat antara (1) kata sebagai satuan fonologis yang membawa makna, (2) makna atau konsep yang dibentuk oleh kata, dan (3) dunia nyata yang ditunjuk (diacu) oleh kata merupakan hubungan referensial. Simbol atau lambang merupakan unsur linguistik berupa kata (kalimat dsb); referen adalah objek atau hal yang ditunjuk (peristiwa, fakta di dalam dunia pengalaman manusia); konsep adalah yang ada pada pikiran kita tentang objek yang diwujudkan melalui lambang. Makna asosiatif berkenaan dengan makna yang dimiliki oleh sebuah kata yang melihat adanya hubungan kata itu dengan keadaan di luar bahasa (Chaer, 2013: 72). Ini berarti, makna asosiatif sama dengan perlambang yang digunakan oleh suatu masyarakat bahasa untuk menyatakan konsep lain dan dihubungkan dengan nilai-nilai moral yang berlaku dalam masyarakat.

Djajasudarma (1993: 30) menyatakan bahwa studi bahasa pada dasarnya merupakan peristiwa budaya. Melalui bahasa, manusia menunjuk dunianya. Dunia penuh dengan nama-nama dan manusia tidak hanya memberi nama pada sesuatu, tetapi juga makna. Bahkan dirinya pun diberi nama dan makna pula. Nama merupakan kata yang menjadi label setiap makhluk, benda, aktivitas, dan peristiwa di dunia ini. Nama-nama tersebut muncul akibat dari kehidupan manusia yang kompleks dan beragam.
Ada hubungan antara nama dan benda (kata-kata merupakan nama, sebagai label dari benda atau peristiwa). Pertanyaan yang muncul dari hal tersebut ialah apakah pemberian nama kepada benda bersifat sewenang-wenang atau dengan perjanjian. Tentu nama bukanlah sebuah perjanjian, tetapi merupakan kesepakatan antara kedua belah pihak orang tuanya. Pemberian nama dari sisi agama memiliki dasar atau dalil, nama yang baik merupakan hak anak terhadap orang tua. Ibnu Qayyim Rahimahullah (dalam Abdillah: 46) berkata bahwa yang dinamai memiliki pengaruh terhadap namanya dalam kebaikan dan kejelekan, dalam ringan dan berat memiliki pengaruh. Plato dalam percakapan yang berjudul Cratylos membahas lambang dan simbol yang bersisi dua, yakni bentuk dan makna (expression dan contents); signifier dan signified. Lambang adalah kata di dalam suatu bahasa, sedangkan makna adalah objek yang kita hayati di dunia yang berupa rujukan atau yang ditujukan oleh lambang tersebut. Oleh karena itu, kata dapat dikategorikan sebagai nama, label suatu benda, aktivitas/atau peristiwa (Plato 429-348 SM) juga pendapat Aristoteles (384-322 SM). Setiap bangsa memiliki nama sendiri untuk setiap benda. Setiap daerah memiliki nama-nama yang berbeda untuk benda yang sama. Dikaitkan dengan pandangan tersebut, manusia adalah benda yang tentunya memiliki nama, sistem pemberian nama itu, tentunya untuk membedakan antara yang satu dengan yang lainnya berdasarkan acuannya.

\section{METODE}

Paradigma yang digunakan untuk membedah sistem penamaan masyarakat Turatea adalah paradigma antropolinguistik dengan teknik survei lapangan, partisipasi (participant observation) peneliti melibatkan diri dalam masyarakatnya. Pengumpulan data pustaka: buku-buku sejarah; wawancara; simak dan catat data yang dikumpulkan berasal dari nama-nama yang hidup sekitar tahun 1900an dan masih ada yang hidup hingga saat ini. Selanjutnya, data dicatat dan diklasifikasikan. 
Langkah berikutnya adalah menerjemahkan data dan menafsirkan makna yang terkandung di dalam nama (data), kemudian data dianalisis. Metode deskriptif kualitatif dengan tujuan mendeskripsikan dan mengungkapkan makna dan nilai di balik penamaan masyarakat Turatea.

\section{PEMBAHASAN}

Penamaan nama diri (propername) pada masyarakat Turatea 'tempo dulu' memiliki keunikan pada arengkale dan areng pakdaengan.Sistem penamaan yang dibagi dua, yaitu nama pertama (arengkarrasa) dan nama kedua yang biasa disebut dengan nama pakdaengan atau pakkaraengang. Kedua nama tersebut mengandung makna dan nilai-nilai budaya masyarakatnya. Hal tersebut tampak setelah nama pertama dikaitkan dengan nama kedua.

\section{Pemaknaan dan Nilai dalam Nama Diri 'arengkale' dan Nama Kedua (Paddaengan)}

Nama I terdiri atas tiga kata, yaitu manurung, Dg. (singkatan dari daeng), dan irate. Kata manurung diidentikkan dengan t(o)aumanurung yang dikenal dengan bukan manusia biasa, tetapi titisan dewa yang turun dari kayangan. Karena anggapan tersebut t(o)aumanurung ini dianggap sebagai bukan keturunan biasa, ia dianggap sebagai keturunan raja atau turunan bangsawan. Dengan anggapan itu pula sebagai manusia yang turun dari tempat yang tinggi ke tempat yang rendah (bumi). Nama ini digunakan pada turunan berikutnya dan digunakan oleh kaum lelaki tetapi dapat pula digunakan oleh perempuan.

Kata I Rate dapat diartikan secara harfiah $I$ dapat berarti kata penunjuk orang, sedangkan rate bermakna 'di atas'. Jika dikaitkan dengan kata Manurung dan irate kedua kata tersebut bertalian secara semantis karena dapat diapresiasikan bahwa orang yang bukan keturunan biasa itu adalah orang yang berasal dari atas (arah). Dari hubungan kedua kata tersebut, menunjukkan pemilik nama tersebut bukanlah berasal dari kalangan biasa.
Nama Mandolangang Dg. Bella dapat dipilah menjadi maddolangang, Dg., dan bella. Kata maddolangang berasal dari kata dolangang 'lautan' yang mendapat imbuhan maK- yang membentuk verba aktif, tetapi dapat juga bermakna 'mengarungi lautan' atau 'mengembara'. Kata bella bermakna 'jauh'. Dari kata maddolangang dan bella mengandung dua makna yang saling berhubungan atau memiliki keterikatan semantis, dalam artian bahwa ketika seseorang yang mengarungi lautan atau mengembara, sudah dipastikan bahwa berdasarkan jarak seseorang berada pada tempat yang jauh. Dengan demikian, kedua kata tersebut mengandung dua hal yang saling berkaitan. Nama dengan kata makdolangan pada masyarakat sekarang sudah sulit ditemukan, yang masih tampak adalah kata bella 'jauh'. Nama ini tetap dipakai untuk mengenang nama kakek agar tetap diingat sepanjang masa.

Nama Mangindara Dg. I Lau juga nama yang diikuti dengan I pada kata lau sebagai penanda persona orang ke dua. Penggunaan I pada zaman ini tidak lagi digunakan jika digunakan sudah dapat dipastikan bahwa orang tersebut berbeda zaman. Kata mangindara mengacu pada nama suatu tempat atau daerah yang letaknya berada di pinggir laut atau bagian barat. Letak laut di Jeneponto terletak di bagian Barat. Kata lau mengacu pada arah mata angin, yaitu bagian barat. Hal ini menunjukkan bahwa kedua nama saling menguatkan/penegasan keberadaan posisi.

Nama Jakkolo Dg. Rangka merupakan nama dari seseorang, nama pertama, yaitu jakkolo yang disebut dengan areng karrasa memiliki makna yang sangat berkaitan erat karena jakkolo merupakan tindakan dan rangka juga merupakan tindakan. Jakkolo semakna dengan jakkala berarti 'tangkap' dan rangka bermakna 'tutup'. Kata jakkala digunakan secara umum baik untuk binatang, maupun manusia atau benda tak bernyawa. Dari kedua nama diri dan nama pakdaengang hubungannya tergambar pada sesuatu yang ditangkap agar tidak dapat lepas, sebaiknya 
ditutup atau dikurung (kalau binatang). Dengan demikian, kedua kata ini merupakan tindakan kedua dilakukan setelah melakukan tindakan pertama. Makna dari kedua kata tersebut ditinjau dari segi hukum, seseorang yang melakukan kesalahan, haruslah diberikan sanksi (hukuman). Ditinjau dari aspek sosial kemasyarakatan yang ditangkap, didapat jika tidak untuk diketahui oleh orang lain, itu disimpan dan tidak dibeberkan pada siapa pun.

Nama Sambila Karaeng Sitaba memiliki arti yang saling berhubungan. Kata sambila berati 'lempar', kata karaeng merupakan penanda status sosial yang tertinggi pada masyarakat Makassar khususnya masyarakat Turatea, dan kata sitaba berasal dari kata dasar taba 'kena' (kata ini merupakan tindakan atau perbuatan) yang mendapat awalan si- 'saling' bermakna 'sesuai atau cocok'. Antara kata sambila dan sitaba memiliki keterkaitan, yaitu jika melempar yang diharapkan adalah melempar sesuai dengan sasarannya. Makna dari kedua kata tersebut adalah adanya sebuah tindakan atau perbuatan haruslah sesuai atau cocok dengan harapan. Dengan kata lain, sesuatu yang dilontarkan harus sesuai dengan perbuatan. Hal ini sesuai dengan konsep hidup orang Turatea. Perkataan harus sesuai dengan perbuatan.

Nama Manyenggolang Daeng Rewa memiliki dua kata yang saling berhubungan, yaitu mennyyenggolang dan rewa. Kata mennyenggolang berasal dari kata senggol yang mendapat imbuhan $M a N G$ - -ang yang melekat pada kata senggol. Kata rewa bermakna 'berani', 'suka berkelahi', dan 'melawan'. Dengan demikian, kedua kata ini memiliki hubungan timbal balik karena hanya orang yang memiliki keberanian yang dapat menyenggol orang lain. Makna dari kata tersebut menyatakan perbuatan atau sifat dari pemilik nama, yaitu pemberani. Menyenggol seseorang hanya dapat dilakukan oleh seorang pemberani dan perilaku di masa itu hanya dapat dilakukan oleh kalangan atas.

Nama Tiru Dg. Palak dapat dilihat hubungannya dengan memperhatikan nama pertama. Kata tiru atau biasa pula dikatakan tiro
(Arief, 1995: 425) bermakna 'ingin', 'harap', 'damba', seperti pada kalimat apa nitirori nakke' apa yang diharapkan dari saya', sedangkan kata palak bermakna 'minta'. Jadi, kedua rangkaian nama tersebut sangatlah berkaitan bahwa apa yang diinginkan atau diharapkan harus diminta dalam pengertian bahwa sesuatu yang diharapkan dan diinginkan senantiasa diminta pada yang kuasa agar sesuai dengan harapan. Nama tiru sudah sulit ditemukan berbeda dengan nama palak, masih dapat ditemukan saat ini. Harapan dari nama tersebut adalah pemilik nama selalu memanjatkan doa. Keinginan itu dapat terwujud jika diminta. Hal ini menunjukkan bahwa yang diharapkan pada pemilik nama adalah selalu bermunajat jika memiliki harapan atau keinginan.

Nama Mangunjungi Dg. Mange dapat diartikan dengan pergi mengunjungi, kata mangunjungi berasal dari kata kunjung yang mendapat afiks $M a K-i$ sehingga menjadi 'mangunjungi' yang berartiverba dengan makna 'mengunjungi, sedangkan kata mange berarti 'ke sana' atau 'kepada'. Dengan demikian, kedua kata tersebut bertalian atau bersinonim dan dapat dimaknai jika mengunjungi seseorang berarti sudah pasti pergi atau berpindah tempat. Ada harapan yang tersembunyi dari nama ini, pemilik nama selalu pergi mengunjungi, diharapkan selalu melakukan silaturahmi.

Nama Kuri Daeng Jalling diperuntukkan untuk anak laki-laki meskipun nama kuri juga digunakan untuk anak perempuan. Kata kuri merupakan singkatan dari kurisi yang berarti 'benci', Jalling bermakna 'lihat'. Dengan demikian, nama pertama memiliki keterkaitan makna dengan nama kedua. Jika seseorang dibenci, orang tersebut tidak disukai untuk dilihat, atau dipandang. Hakikat dari nama tersebut yang diharapkan adalah janganlah menjadi orang yang dibenci karena orang yang dibenci akan tidak disukai dilihat atau dipandang. Dengan demikian ada harapan bahwa jadilah selalu orang yang disayangi atau disukai sehingga selalu dirindukan. 
Nama Massulukang Karaeng Lalang berasal dari kata massulukan dan lalang, dua buah kata yang berantonim kata massulukang berasal dari kata suluk yang berarti 'keluar' mendapat imbuhan ma- dan akhiran -ang sehingga menjadi massulukang, sedangkan kata lalang berarti 'dalam'. Dengan demikian, nama Massulukang $\mathrm{Kr}$ lalang dapat dimaknai meskipun keberadaan dirinya semakin jauh, tetapi harus tetap menjadi bagian dari keluarga.

Nama Bebasa Kr Lalo berasal dari kata bebasa dan lalo. Kata bebasak berarti 'bebas', sedangkan lalo berarti 'lalu', 'lampau', atau 'lewat'. Dengan demikian, kedua kata ini bersinonim dan nama tersebut dapat dimaknai terlalu atau terlampau bebas. Hal ini sekaitan dengan kebiasaan untuk mengontrol atau menjaga diri. Nama ini berisi nasihat ketika diberi kebebasan patut mengetahui batas-batasnya dan menjaga kepercayaan yang diberikan.

Nama Kalepu Dg. Gassing adalah dua kata yang saling berkaitan secara semantis. Kata Kalepu bermakna 'utuh' dan Gassing memiliki arti 'kuat' atau sehat. Dari kedua kata tersebut dapat dimaknai bahwa kekuatan itu harus utuh. Makna dan nilai sosial yang diberikan nama tersebut adalah keutuhan dalam persatuan akan menciptakan kekuatan.

Nama Rakra Dg. Jannang. Kata rakra yang diartikan 'nyenyak' atau 'pulas'digunakan dalam lingkup yang lebih khusus, yaitu berkaitan dengan kenyamanan dalam tidur, sedangkan kata jannang memiliki makna yang lebih luas yang berarti ketenangan. Jika dilihat dari kedua makna kata, nama tersebut dapat diartikan bahwa orang yang nyenyak tidurnya akan tenang hatinya. Kata rakrak dan jannang merupakan dua kata yang bersinonim yaitu berkaitan dengan persoalan tidur, seperti rakraki tinrona 'nyenyak tidurnya', atau jannangngi tinrona 'nyenyak tidurnya'. Kedua kata tersebut dapat saling menggantikan dalam konteks kalimat tersebut dan maknanya pada hakikatnya berbeda. Ada harapan di dalam nama tersebut, yaitu di dalam jiwa ada ketenangan atau senantiasa menjaga ketenangan jiwanya.
Nama Manggaukang $k r$ Maling. Kata manggaukang berasal dari kata gauk yang berarti 'kerja', 'perubahan', dan 'daya' yang mendapat imbuhan mang- dan -ang. Dengan demikian, kata manggaukang berarti pekerjaan. Kata maling diambil dari kata reduplikasi, yaitu maling-maling yang bermakna 'rasa kasihan' atau 'cinta'. Kedua kata yaitu manggaukang dan maling memiliki hubungan perbuatan yang membutuhkan rasa kasih sayang. Dengan makna peringatan/nasihat bahwa meskipun melakukan sesuatu hal/tindakan tetap mempertimbangkan rasa belas kasihan.

Nama Buttuli Dg. Ruppa merupakan dua kata yang bersinonim. masih kita temukan saat ini karena yang memiliki nama masih hidup. Nama Dg. Ruppa masih digunakan untuk nama cucu dan keluarga kerabatnya. Nama ini diambil dari nama nenek moyang mereka agar orang yang sudah tiada tetap dikenang dengan mempertimbangkan bahwa pemilik nama tersebut memiliki sifat dan perangai yang patut ditiru atau dicontoh. Kata Buntuli berasal dari kata buntuluk artinya 'temu', 'jumpa', 'dapat' dan ruppa berarti 'temu' dan 'jumpa'. Kata buntuluk bila ditambahkan afiks $-i$, dapat bermakna 'menemui'. Dalam budaya Turatea setiap akan melakukan hajatan, sanak saudara dekat dibuntuli 'ditemui atau diundang dengan cara langsung, yaitu tanpa menggunakan undangan' untuk datang ke hajatan yang mengundang. Dengan demikian, nama ini mengandung nasihat bahwa ketika mengundang, orang yang diundang diperlakukan dengan baik, yaitu disapa atau ditemui (beri muka).Hal ini mengharapkan adanya sikap saling menghargai sesama keluarga atau orang lain.

Nama Barak Dg. Sarro memiliki keterkaitan dengan gejala alam, yaitu, musim hujan. Barak 'musim penghujan,' sedangkan kata sarro bermakan 'keras,' 'deras.' Musim hujan adalah musim yang sangat dinanti-nantikan oleh orang Turatea karena musim ini dianggap sebagai musim yang membawa keberkahan dan kehidupan bagi masyarakatnya. Air merupakan sumber kehidupan utama dan penting dalam 
kehidupan. Harapan dari musim barak 'hujan' adalah hujan deras sehingga semua tanaman dan persawahan mendapatkan air.

Nama Gunturu Dg. Makro berasal dari dua kata, yaitu gunturu dan Makro. Kedua kata ini memiliki keterkaitan dengan gejala alam. Kata gunturu berkategori nomina yang bermakna 'guntur' dan Makro 'suara guntur yang keras.' Secara logika, guntur akan mengeluarkan bunyi dan suara yang keras.

\section{Pemaknaan Nama dan Nilai pada Nama Perempuan}

Nama Lamari Dg. Konci diambil dari dua nama kata benda, yaitu lamari 'lemari,'konci 'kunci. 'kedua benda ini saling berkaitan. Lemari untuk menyimpan sesuatu yang dapat diketahui atau tidak oleh orang lain dan selayaknya menggunakan kunci. Jadi, kedua benda ini pada dasarnya saling berkaitan. Lemari adalah tempat menyimpan sesuatu yang berharga sejak zaman dahulu hingga saat ini. Lemari menggunakan kunci untuk membuka atau mengunci sesuatu. Yang diharapkan adalah kepandaian menyimpan atau menjaga barang yang berharga.

Nama Carammeng Dg. Kaca adalah nama yang diambil dari kata benda. Kata carammeng 'cermin' dan kaca 'kaca.' Cermin merupakan salah satu jenis kaca yang penting karena sebagai alat bantu untuk melihat refleksi bagian tubuh yang tidak dapat dilihat langsung oleh mata kita. Harus diakui, fungsi inilah yang berkembang sejak zaman dahulu. Bahkan cermin menjadi bagian dari kehidupan masyarakat berkat kemampuannya membantu manusia merias diri dan mengoreksi penampilan. Makna dari kedua nama tersebut adalah kita seharusnya bisa mengontrol diri.

Nama Basse Dg. Intang merupakan dua nama dari kata benda. Kata basse merupakan sebutan untuk nama anak perempuan (simbol perempuan) sedangkan intang berarti 'intan.' Intan adalah jenis batu permata yang memiliki harga jual yang tinggi. selain itu, intan juga dapat memancarkan cahaya yang tidak dimiliki oleh permata lainnya Nama ini mengharapkan bahwa anak perempuannya bagaikan intan yang bercahaya.

Nama Suruga Dg. Baji adalah nama yang diambil dari kata benda yang dipadukan dengan kata sifat. Kata suruga bermakna 'surga,' sedangkan kata baji berarti 'baik.' Kedua nama ini berkaitan karena tidak seorang pun yang menyatakan bahwa surga itu tidak baik dan dapat dipastikan bahwa orang akan menyatakan bahwa surga itu baik. Karena berdasar pada hal tersebut sehingga kata suruga' surga' dipasangkan dengan kata bajik' baik.' Nama suruga sudah jarang ditemukan yang masih dapat ditemukan adalah nama bajik. Nama ini tetap dipertahankan untuk mengenang nenek dan mengetahui asal keturunanya. Makna kata surugadg. Baji, ada harapan orang tua bahwa nama anaknya kelak dapat menggapai surga karena surga itu baik.

Nama Basa Dg. Jekne ditemukan pula nama Basaria Dg. Jekne. Nama basaria berasal dari kata basa yang ditambahkan dengan ria. Kata ria merupakan penanda untuk perempuan. Kata basa dalam bahasa Makassar diartikan 'basah.' Keterkaitan kata basa dan jeknek. jika seseorang jekne 'mandi' menyebabkan orang menjadi basa. Dengan demikian tampak bahwa nama kedua (areng pakdaengang) merupakan penyebab dari nama pertama (areng karrasa). Makna yang menunjukkan rangkaian nama tersebut adalah perempuan memiliki sifat-sifat seperti air yang senantiasa menjaga kebersihan dirinya.

Nama Kurisi Dg. Ngai merupakan nama untuk perempuan yang terdiri atas dua kata yang berantonim. Kata kurisi memiliki arti 'benci,' sedangkan kata ngai berarti 'suka.' Selain digunakan kata kurisi, ada pula yang menggunakan nama tersebut dengan disingkat menjadi kuri. Ini berarti dibenci, tetapi disukai juga, dalam artian 'benci tapi dirindukan.'

Nama Minasai Dg. Sunggu adalah dua nama saling memiliki keterkaitan. Kata minasai diambil dari kata minasa yang berarti 'cita-cita,' yang ditambah dengan akhiran -i 
sebagai penegas, sedangkan sunggu berarti 'bahagia' atau 'sejahtera.' Ada harapan pada nama tersebut, orang tua pemilik nama tersebut berharap jika kelak mendapat kebahagiaan dan kesejahteraan dan yang dicita-citakan tercapai.

Nama Mania Dg. Tekne adalah dua kata yang diambil dari kata sifat. Kata mania berasal dari kata nia 'ada' yang ditambahkan dengan prefiks $m a$ - yang bermakna aktif. Kata tekne berarti 'manis.' Dengan demikian, pemilik nama ini diharapkan menjadi orang yang berada dan tidak kekurangan sehingga mendapatkan kebahagiaan dalam kehidupan.

\section{Sistem Pemberian Nama berdasarkan Nama Hari}

Orientasi pemberian nama berdasarkan hari lahir dengan mempertimbangkan agar hari lahir sang anak diketahui sepanjang masa. Hal ini menandakan bahwa waktu sangat penting untuk diingat. Anak yang lahir pada hari Senin diberi nama sanneng, yang lahir pada hari Selasa diberi salasa, yang lahir pada hari Rabu memiliki banyak pilihan, yaitu rabaseng, rabanai, rabanong, rabali, rabaniah, atau rabiah; yang lahir pada hari Kamis diberi nama kammisi atau kamisa. Yang lahir pada hari Jumat diberi nama jumakkara, jumaseng, jumaing, jumariah, jumasiah, atau pun jumriah. Yang lahir pada hari Sabtu diberi nama sattu, sattuang, atau sattudeng. Yang lahir pada hari Minggu diberi nama minggu atau I ahak.

Pemberian nama berdasarkan hari dapat menunjukkan kelas sosial. Nama-nama tersebut tidak memiliki pasangan/nama kedua sehingga seseorang yang memiliki nama sanneng, misalnya, maka untuk menjaga kesantunan antara sesama kelas sosial akan menyebut sanneng atau Dg. Sanneng. Jumatia dipanggil dengan Dg. Juma. Jadi, nama 'pakdaengan' digunakan sebagai penghormatan kepada yang lebih tua dengan mengambil bagian awal atau bagian akhirnya saja untuk memudahkan pengucapan.

Nama-nama hari yang dapat digunakan sebagai nama diri, seperti

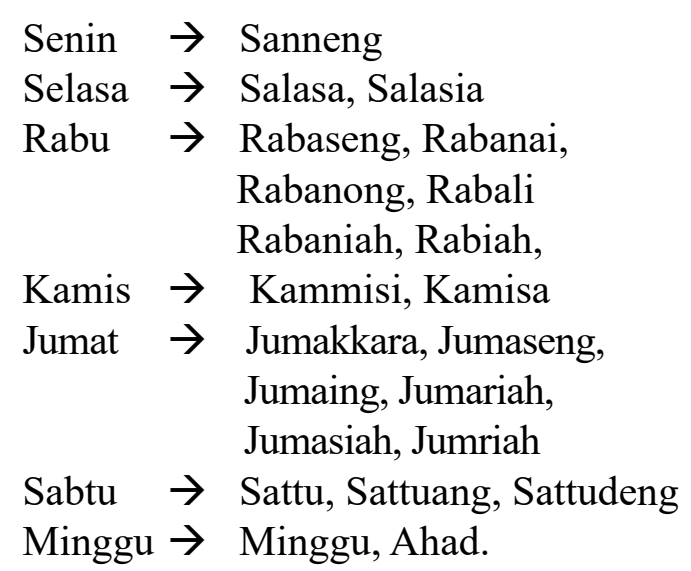

\section{Sistem Pemberian Nama berdasarkan Agama}

Tokoh agama menjadi pilihan dalam pemberian nama. Nama islami, nabi atau keluarga nabi, seperti Abdul Rahim Dg. Rangka.. Abdul Rajab Dg. Nippa, Sitti Aminah Dg. Nurung, St. Saodah Dg. Puji, Suruga Dg. Baji atau Saharia Dg. Pakja. Nama diri dan nama pakdaengang tidak memiliki keterkaitan secara semantik. Nama dari kaum laki-laki memiliki variasi bentuk, seperti

$\begin{array}{lll}\text { Abdullah } \rightarrow & \begin{array}{l}\text { bado, badu, dullah, } \\ \text { badullah, bodallahi }\end{array} \\ \text { Idris } & \rightarrow & \text { diri, diris, dariso, I dirrisi } \\ \text { Ibrahim } & \rightarrow & \text { Rahing, I Bora, Iborahima, } \\ & \text { I Borahing, Dorahing } \\ \text { Zakaria } & \rightarrow \quad \text { zakari, zahari } \\ \text { Rajab } & \rightarrow \quad \text { Rajab atau rakjak }\end{array}$

Nama-nama tersebut secara fonologis mengalami perubahan, baik dari segi pelesapan, penambahan, dan penggantian fonem.

\section{Budaya Masyarakat Turatea dalam Pemberian Nama}

Penamaan diri masyarakat Turatea dilakukan melalui proses, yaitu (1) memberikan nama kepada bayi 'aktopolo/anngalleareng' dengan melalui upacara ritual yang biasanya dilakukan dengan memotong kambing dan mengundang sanak saudara atau secara Islami disebut akkekah (akikah). Istilah aktopolo mulai tergantikan dengan istilah akkekah ini. Pada dasarnya kedua istilah ini berbeda proses ritualnya dan waktu pelaksanaannya. Aktopolo 
dilakukan tanpa mempertimbangkan waktu pelaksanaan. yang menjadi pertimbangan adalah kemampuan/kesanggupan orang tua dari segi waktu yang dianggap baik dan keuangan. Jadi, kapan saja orang tua sang bayi mampu melaksanakannya baru dapat dilaksanakan. Akkekah mempertimbangkan waktu yang afdal dilakukan dan kesanggupan/kemampuan finansial.

Pada saat ini akkekah ini tidak hanya dilakukan pada saat bayi, melainkan juga dilakukan setelah tua karena menganggap dirinya sudah mampu. Padahal, secara Islami akikah dilakukan secepatnya setelah tujuh hari atau sebelum empat puluh hari, sesuai dengan kemampuan keluarga yang baru memiliki anak.

Pada saat lahir sang bayi diberi nama acce (perempuan) atau aco (laki-laki). Ketika aktopolo (akikah) sang bayi dipilihkan nama oleh orang tuanya diistilahkan dengan nama keramat/nama diri (areng karrasa) yang nantinya digunakan dalam dokumen resmi. Nama diri ini berlaku bagi seluruh anggota masyarakat dan dianggap sebagai nama yang digunakan dalam dokumen-dokumen resmi, baik dari kalangan atas maupun sampai kalangan bawah. Dari nama diri/nama keramat (areng karrasa) ini sang bayi diberi nama kecil (areng cakdi) yang biasanya diambil dari singkatan nama diri atau nama pakdaengang. Penggunaan/penyebutan nama diri pada kalangan atau usia tertentu terhadap seseorang harus mengikuti norma yang berlaku dalam masyarakatnya,

Proses pemberian nama ini bervariasi, nama kedua areng paddaengan biasanya mengikut pada areng karrasa atau pada saat di akikah, tetapi umumnya tidak disertakan pada pengambilan nama areng karrasa/topolo. Yang terpenting adalah nama diri (areng karrasa).

Nama pakdaengang, biasanya tidak digunakan pada saat masih kecil meskipun ada juga yang menggunakannya sejak kecil sehingga seseorang terkadang tidak dikenal nama dirinya. Pakdaengan ini akan melekat setelah punya adik, remaja atau dewasa atau setelah menikah.
Paddaengan adalah nama yang dapat digunakan oleh seseorang yang sekaligus menjadi nama kehormatan pada kalangan tertentu. Begitu pula dalam pemberian nama diri yang diikuti dengan karaeng. Adanya nama kedua (paddaengan) tidak melihat perbedaan usia, tetapi nama paddaengan diberikan kepada orang yang terlahir dari keluarga yang memiliki areng paddaengan dan menganggap bahwa yang memiliki nama pakdaengan bukanlah orang biasa berdasarkan struktur budaya. Kendatipun pada dasarnya semua manusia adalah sama di mata sang pencipta.

Hingga zaman modern saat ini kedua nama daeng (areng pakdaengang) atau nama karaeng (pakkaraengang) masih tetap dianggap sebagai sesuatu yang bernilai dimata masyarakatnya karena masih dianggap sebagai penanda stratifikasi sosial. Selain itu, dianggap sebagai upaya mengenang dan mengingat nama orang tua/tokoh terdahulu.

Kata pakkaraengan berasal dari kata karaeng. Kata karaeng ini merupakan gelar yang disematkan kepada seseorang yang memegang pemerintahan sebagai pemerintah suatu wilayah. Yang selanjutnya digunakan oleh keturunan pejabat pemerintah wilayah. Kata karaeng yang melekat pada nama seseorang dianggap sebagai turunan bangsawan. Padahal gelar ini tidak semua orang berhak menggunakannya.

Seseorang yang sudah diberi nama pakdaengang tidak bisa lagi diberi nama pakkaraengang. Nama pakkaraengan pada dasarnya diperuntukkan bagi orang yang memegang jabatan dalam wilayah kekuasaan yang dapat berarti raja atau dengan kata lain pakkaraengan diberikan ketika seseorang dinobatkan menjadi penguasa, tetapi kini pakkaraengan diberikan atau diikutkan ketika memberi nama kepada anak yang dianggap sebagai keturunan bangsawan sejak masih kecil.

Arengkale atau nama diri memiliki makna dan arti yang strategis dalam masyarakat Turatea. Selain itu, dapat membedakan kelompok sosial masyarakatnya serta dapat 
menunjukkan harapan orang tua terhadap perilaku si pemilik nama yang bersangkutan.

Nama-nama tertentu yang digunakan dalam masyarakat biasanya mengungkapkan latar alam dan budaya (natural and cultural background) yang melingkupinya. Penggunaan nama diri yang berbeda secara kultural mengklasifikasikan manusia dalam kelompokkelompok dengan identitas yang berbeda. Selain itu, dapat merekonstruksi realitas dalam kaitannya dengan hubungan sosial dalam masyarakatnya. Kendatipun, makna sebuah nama di satu sisi dapat merefleksikan kebudayaan yang melingkupinya. Di sisi lain, makna bisa juga tidak direfleksikan, tetapi dikonstruksi oleh masyarakat.

\section{PENUTUP}

Berdasarkanhasiltelaah, dilihatdari sistem pemberian nama diri dan nama pakdaengan secara leksikal sarat dengan makna; bersinonim, berantonim, dan berlogika semantik. Selain itu, juga memperhatikan kelas kata, yaitu benda, sifat, kerja, dan keterangan. Pemberian nama dilakukan dengan memperhatikan nilai budaya, gejala alam, dan aspek keagamaan. Nilai dan harapan yang dikandung oleh kedua nama yang dipilih menandakan bahwa nama yang dipilih mengandung petuah untuk kebaikan dan sikap yang harus dilakukan dalam menjalani kehidupan, baik untuk diri sendiri maupun untuk orang lain. Hasil penelitian dapat dijadikan sebagai bahan ajar di sekolah-sekolah, agar anak lebih mengenal kosa-kata dan makna dari kata yang sudah mulai ditinggalkan. Nama yang dipilih oleh orang tua sebaiknya memilih kata-kata yang indah yang di dalamnya mengandung permainan bahasa yang indah dan doa. Nama yang baik dengan kata yang indah akan memberikan nilai bagi pemilik nama.

\section{DAFTAR PUSTAKA}

Abbas. (2012) Sistem Tradisional Penamaan Diri Orang-Orang Makassar-Indonesia. Prosiding Kongres Internasional II
Bahasa-Bahasa Daerah Sulawesi Selatan, hlm. 344-354. Makassar: Balai Bahasa Prov. Sulawesi Sealatan dan Prov. Sulawesi Barat, Badan Pengembangan dan Pembinaan Bahasa Kemdikbud Pemerintah Provinsi Sulawesi Selatan.

Arief, Aburaerah. (1995), Kamus MakassarIndonesia. Ujung Pandang: Yayasan Perguruan Islam Kapita*DDI*.

Bin Abdillaah, Abdussalaam. (2017) Pendidikan Anak dalam Cahaya Al-Qur'an dan AsSunnah. Untuk kalangan sendiri.

Chaer, Abdul. (2013), Pengantar Semantik Bahasa Indonesia. Jakarta: Rineka Cipta.

Djajasudarma, T. Fatimah. (1993), Semantik Pengantar ke Arah Ilmu Makna. Bandung: Erasco.

\section{------. (1999), Pemahaman Ilmu Makna. Bandung: Refika Aditama.}

Duranti, Alessandro. (2000), Linguistic Anthropology. Reprinted. Cambridge: Cambridge University Press.

Hasyim, Munirah (2016). Perubahan Sistem Penamaan Nama Diri https://docplayer. info/55876222-Munira-hasyim-dosenpada-jurusan-sastra-indonesia-fakultasilmu-budaya-universitas-hasanuddinmakassar.html diakses pada pukul 8.00. Diakses pada tanggal 24 Januari 2019.

Hymes, Dell. (1964), Languange in Culture and Society. New York: Harper and Row.

Iswary, Erydan Rahim bin Aman. (2001). "Acculturation of Language and Culture through Manifestation of Lexical Usage in Cross Indonesia-Malay Language” dalam Jurnal Melayu, hlm. 49-56. Diakses dari http//www.ukm.my pada tanggal 5 Januari 2015.

Kramsch, Claire. (1998), Language and Culture. Oxford: Oxford University Press.

----------.(2000), Language and Cultur. Oxford: oxford University Press.

Kridalaksana, Harimurti. (1993). Kamus Linguistik. Jakarta: Gramedia.

Kurniawaty, Laila. (2007) Pemberian Nama dalam Masyarakat di Pulau Binongko, 
Kandai: Majalah Ilmiah Bahasa dan Sastra, Volume 1, Tahun II, Juli 2007, hlm. 34--46. Kantor Bahasa Provinsi Sulawesi Tenggara.

Maknun, Tadjuddin. (2010) Lontarak: Arti. Asal Usul dan Nilai Budaya yang Dikandungnya dalam Industri Budaya-Budaya Industri: Kongres Kebudayaan Indonesia 2008; hlm. 667--679.

Pateda, Mansoer. (2010), Semantik Leksikal. Jakarta: Rineka Cipta.

Sariah. (2012). Antroponimi dalam Obituari Keturunan Tionghoa: Sebuah Tinjauan Deskriptif. Metalingua: Jurnal Penelitian Bahasa, Vol. 10, No.2, hlm. Desember 2012. Jawa Barat: Balai Bahasa Provinsi Jawa Barat.
Sibarani, Robert. (1993), Pemberian Nama sebagai Awal Pemunculan Linguistik: Makna Nama dalam Bahasa Nusantara. Bandung: PT Bumi Siliwangi. (2003). Kearifan Lokal Hakikat, Peran, dan Metode Tradisi Lisan. Jakarta : Asosiasi Tradisi Lisan. -. (2004), Antropolinguistik: Antropologi Linguistik, Linguistik Antropologi. Medan: Penerbit Poda.

Spradley, James P. (2006). Metode Etnografi. Yogyakarta: Tiara Wacana, Edisi I.

Sufika, Arwina, (2007), Fungsi Bahasa dalam Perspektif Promosi Pariwisata" dalam Chaiyanara (editor) Kesinambungan dan Pemantapan Bahasa di Asia Tenggara. Singapura: Rancangan Pertumbuhan Linguis ASEAN. 